Praxis : Jurnal Sains, Teknologi, Masyarakat dan Jejaring | Vol. 3 | No. 2 | Maret 2021

\title{
Penerapan Prinsip Good Corporate Governance Terhadap Program Corporate Social Responsibility Pada PT. Jasa Marga (Persero) Tbk. Jasa Marga Transjawa Tollroad Regional Division Representative Office 2 Semarang
}

\author{
Maria Theresia Heni Widyarti ${ }^{1}$; Larasati Kurniawan ${ }^{2}$ \\ Politeknik Negeri Semarang \\ JL. Prof. H. Soedarto, Tembalang, Semarang, Jawa Tengah, 50275 \\ email: ${ }^{1}$ heniwidyarti67@gmail.com; ${ }^{2}$ larasatikurniawan22@gmail.com
}

\begin{abstract}
This research aims to analyze the principles of Good Corporate Governance on the application of Corporate Social Responsibility. This research was conducted at Jasa Marga Transjawa Tollroad Regional Division Representative Office 2 Semarang. The type of data in this study is primary data obtained through interviews and observations. The sampling technique used was purposive sampling. The sample in this study were 18 respondents. The data analysis method used is descriptive qualitative analysis method. The results showed that Jasamarga carried out its Corporate Social Responsibility activities with 2 (two) programs, the Partnership Program and the Community Development Program. Jasamarga RD RO 2 Semarang has carried out its commitment by realizing 21 Community Development programs which are divided into 8 places of worship, 8 educational facilities and 5 public facilities as well as 119 partnership sectors consisting of 32 industries, 23 services, 55 trades, 1 fishery, and 8 the farm. Implementation of Good Corporate Governance Principles in Jasamarga Corporate Social Responsibility Program by implementing the Principles of Transparency, Accountability, Responsibility, Independency and Fairness. The principles of Accountability, Responsibility and Independence have been implemented very well, the principles of transparency have been implemented well and the principles of fairness have been implemented quite well.
\end{abstract}

Keywords : Good Corporate Governance, Corporate Social Responsibility

\begin{abstract}
Abstrak
Penelitian ini bertujuan untuk menganalisis penerapan rinsip Good Corporate Governance terhadap penerapan Corporate Social Responsibility. Penelitian ini dilaksanakan di Jasa Marga Transjawa Tollroad Regional Division Respresentative Office 2 Semarang. penelitian ini menggunakan data primer yang diperoleh melalui hasil wawancara dan observasi. Teknik pengambilan sampel yang digunakan adalah purposive sampling. Sampel dalam penelitian ini sebanyak 18 responden. Metode analisis data yang digunakan adalah metode analisis deskriptif kualitatif. Hasil penelitian menunjukkan bahwa Jasamarga melaksanaan kegiatan Corporate Social Responsibility dengan 2 (dua) program yaitu, Program Kemitraan dan Program Bina Lingkungan. Jasamarga RD RO 2 Semarang telah melaksanakan komitmennya dengan merealisasi 21 program Bina Lingkungan yang terbagi pada 8 sarana ibadah, 8 sarana pendidikan, dan 5 sarana umum serta 119 sektor kemitraan yang terdiri dari 32 industri, 23 jasa, 55 perdagangan, 1 perikanan, dan 8 peternakan. Penerapan Prinsip- Prinsip Good Corporate Governance pada Program Corporate Social Responsibility Jasamarga dengan melaksanakan Prinsip Transparasi (transparency), Akuntabilitas (accountability), Bertanggung Jawab (Responsibility), Kemandirian (Independency)dan Kewajaran (Fairness). Prinsip Akuntabilitas, Bertanggungjawab dan Kemandirian sudah dijalankan dengan sangat baik, prinsip Transparansi sudah dijalankan dengan baik dan prinsip Kewajaran sudah dijalankan dengan cukup baik.
\end{abstract}

Kata Kunci: Good Corporate Governance, Corporate Social Responsibility 


\section{PENDAHULUAN \\ Latar Belakang Penelitian}

Good Corporate Governance merupakan suatu keharusan dalam rangka membangun kondisi perusahaan yang hebat, tangguh dan berkelanjutan. Pelaksanaan Good Corporate Governance yang tidak dilaksanakan dengan baik memiliki potensi untuk mempengaruhi perusahaan tersebut. Oleh karena itu, peran Good Corporate Governance dalam suatu perusahaan sangat penting.

Pada tahun 2019, Indonesia dikejutkan dengan adanya kasus penyelewengan Good Corporate Governance yang dilakukan oleh perusahaan BUMN yaitu PT. Garuda Indonesia dan PT. Krakatau Steel. Penyelewengan yang dilakukan oleh PT. Garuda Indonesia yaitu kesalahan pelaporan keuangan mengenai dana untuk kesejahteraan karyawan yang dilaporkan dalam penggunaan dana Corporate Social Responsibility. Hal ini menunjukkan bahwa penerapan Good Corporate Governance yang dilakukan perusahaan sangatlah minim. Di Indonesia, penerapan Good Corporate Governance bersifat wajib dan mutlak dilaksanakan oleh semua sektor usaha, non keuangan maupun keuangan, hal ini sesuai dengan UndangUndang No. 40 Tahun 2007 tentang Perseroan Terbatas. Kebijakan UndangUndang dalam penerapan Corporate Governance antar sektor usahapun berbeda-beda. Semua perusahaan membutuhkan Good Corporate Governance temasuk perusahaan milik pemerintah sekalipun. Penerapan praktek Good Corporate Governance berdasarkan Peraturan Menteri Negara Badan Usaha Milik Negara Nomor: PER-01/MBU/2011 tanggal 01 Agustus 2011 tentang Penerapan Tata Kelola Perusahaan Yang Baik (Good Corporate Governance) pada Badan Usaha Milik Negara (BUMN) dan perubahannya Nomor: PER-09/MBU/2012 tanggal 6 Juli 2012.
PT. Jasamarga Transjawa Tollroad RD RO 2 Semarang sebagai Badan Usaha Milik Negara (BUMN) yang sahamnya dimiliki pemerintah dan publik. PT Jasa Marga (Persero) Tbk telah menjalankan Good Corporate Governance sesuai dengan anjuran pemerintah. Terdapat lima prinsip utama dalam penerapan Good Corporate Governance secara umum yang terdiri atas transparansi, akuntabilitas, responsibilitas, independensi dan keadilan (KNKG, 2006 : 12). Salah satu implementasi prinsip responsibilitas diterapkan dalam bentuk tanggung jawab sosial perusahaan yang disebut dengan Corporate Social Responsibility. Pelaksanaan Corporate Social Responsibility yang baik diharapkan mampu meningkatkan citra positif perusahaan. Dengan demikian perusahaan diharapkan dapat menjalankan programprogram Corporate Social Responsibility secara berkelanjutan. Penerapan prinsipprinsip Good Corporate Governance diharapkan dapat membantu mewuiudkan praktek Corporate Social Responsibility, karena implementasi dan tanggungjawab sosial perusahaan tidaklah terlepas dari penerapan Good Corporate Governance di dalam perusahaan tersebut, yang akan mendorong manajemen untuk mengelola perusahaan secara benar termasuk mengimplementasikan tanggung jawab sosialnya.

\section{Masalah Penelitian}

PT. Jasamarga Transjawa Tollroad RD RO 2 Semarang merupakan salah satu perseroan terbatas yang memiiki nama ditingkat nasional. PT. Jasamarga Transjawa Tollroad RD RO 2 Semarang telah menerapkan program Corporate Social Responsibility guna menunjang salah satu prinsip dari Good Corporate Governance yaitu responsibility. Penerapan Good Corporate Governance dan Corporate Social Responsibility dapat mendorong nilai dan citra perusahaan menjadi lebih baik. Dengan demikian perlu untuk menganalisis bagaimana penerapan 
prinsip-prinsip Good Corporate Governance pada program Corporate Social Responsibility perusahaan pada PT. Jasamarga Transjawa Tollroad RD RO 2 Semarang.

Berdasarkan latar belakang penelitian ini maka masalah dalam penelitian ini adalah: Bagaimana penerapan prinsip-prinsip Good Corporate Governance terhadap program Corporate Social Responsibility perusahaan pada PT. Jasamarga Transjawa Tollroad RD RO 2 Semarang.

\section{TINJAUAN PUSTAKA \\ Perusahaan Perseroan (Persero)}

Menurut UU Nomor 19 tahun 2003 tentang Badan Umum Milik Negara, BUMN adalah badan usaha yang seluruh atau sebagian besar modalnya dimiliki oleh negara melalui penyertaan secara langsung yang berasal dari kekayaan negara yang dipisahkan. BUMN terdiri dari Perusahaan Perseroan (Persero) dan Perusahaan Umum (Perum). Perusahaan Perseroan (Persero) adalah BUMN yang berbentuk perseroan terbatas yang modalnya terbagi dalam saham yang seluruh atau paling sedikit 51 $\%$ (lima puluh satu persen) sahamnya dimiliki oleh Negara Republik Indonesia yang tujuan utamanya mengejar keuntungan. Perusahaan Perseroan (Persero) memiliki struktur organisasi yang dikepalai oleh Direksi.

\section{Good Corporate Governance dalam Perusahaan Perseroan (Persero)}

Perusahaan Perseroan (Persero) memiliki peran yang signifikan dala pegelolaan asset yang dimiliki negara. Dalam hal ini untuk dapat mengoptimalkan perannya dan mampu mempertahankan keberadaannya dalam perkembangan ekonomi dunia yang semakin terbuka dan kompetitif, Perusahaan Perseroan (Persero) perlu menumbuhkan budaya korporasi dan profesionalisme antara lain melalui pembenahan pengurusan dan pengawasannya. Pengurusan dan pengawasan perusahaan Badan Usaha Milik Negara (BUMN) harus dilakukan berdasarkan prinsip-prinsip tata-kelola perusahaan yang baik (Good Corporate Governance).

Konsep Good Corporate Governance di Indonesia diartikan sebagai konsep tata kelola perusahaan yang baik. Dua hal yang ditekankan dalam konsep Good Corporate Governance tersebut yaitu pentingnya hak pemegang saham untuk memperoleh informasi dengan benar serta tepat waktu dan kewajiban perusahaan untuk melakukan pengungkapan secara akurat, tepat waktu dan transparan terhadap semua informasi kinerja perusahaan, kepemilikan, dan stakeholder. Menurut Peraturan Menteri Negara Badan Usaha Milik Negara Nomor 01/MBU/2011 halaman 4, BUMN wajib menerapkan Good Corporate Governance secara konsisten dan berkelanjutan dengan berpedoman pada Peraturan Menteri ini dengan tetap memperhatikan ketentuan, dan norma yang berlaku serta anggaran dasar BUMN. Prinsip-prinsip Good Corporate Governance yang dimaksud dalam peraturan ini, meliputi:

a. Transparansi (transparency), yaitu keterbukaan dalam melaksanakan proses pengambilan keputusan dan keterbukaan dalam mengungkapkan informasi material dan relevan mengenai perusahaan.

b. Akuntabilitas (accountability), yaitu kejelasan fungsi, pelaksanaan dan pertanggungjawaban organ sehingga pengelolaan perusahaan terlaksana secara efektif.

c. Pertanggungjawaban (responsibility), yaitu kesesuaian di dalam pengelolaan perusahaan terhadap peraturan perundang-undangan dan prinsipprinsip korporasi yang sehat

d. Kemandirian (independency), yaitu keadaan di mana perusahaan dikelola secara profesional tanpa benturan 
kepentingan dan pengaruh/tekanan dari pihak manapun yang tidak sesuai dengan peraturan perundang-undangan dan prinsip-prinsip korporasi yang sehat.

e. Kewajaran (fairness), yaitu keadilan dan kesetaraan di dalam memenuhi hak-hak Pemangku Kepentingan (stakeholders) yang timbul berdasarkan perjanjian dan peraturan perundangundangan.

\section{Manfaat dan Tujuan Good Corporate Governance}

Menurut Forum for Corporate Governance in Indonesia (FCGI:2001) manfaat dari penerapan Good Corporate Governance adalah :

a. Meningkatkan kinerja perusahaan melalui terciptanya proses pengambilan keputusan yang lebih baik, meningkatkan efisiensi operasional perusahaan serta lebih meningkatkan pelayanan kepada stakeholders.

b. Mempermudah diperolehnya dana pembiayaan yang lebih murah (karena faktor kepercayaan) yang pada ahkirnya akan meningkatkan corporate value.

c. Mengembalikan kepercayaan investor untuk menanamkan modalnya di Indonesia.

d. Pemegang saham akan merasa puas dengan kinerja perusahaan karena sekaligus akan meningkatkan shareholders value dan deviden. Khusus bagi BUMN akan dapat membantu bagi APBN terutama hasil privatisasi.

Penerapan Good Corporate Governance dilingkungan BUMN mempunyai tujuan sesuai Peraturan Menteri Negara BUMN No. PER-01/MBU/2011 halaman 4, pada Badan Usaha Milik Negara, yaitu :

1. Megoptimalkan nilai BUMN agar perusahaan memiliki daya saing yang kuat, baik secara nasional maupun internasional, sehingga mampu mempertahankan keberadaannya dan hidup berkelanjutan untuk mencapai maksud dan tujuan BUMN.

2. Mendorong pengelolaan BUMN secara professional, efesien, dan efektif, serta memberdayakan fungsi dan meningkatkan kemandirian Organ Persero/ Organ Perum.

3. Mendorong agar Organ Persero/Organ Perum dalam membuat keputusan dan menjalankan tindakan dilandasi nilai moral yang tinggi dan kepatuhan tehadap peraturan perundangundangan, serta kesadaran akan adanya tanggung jawab sosial BUMN tehadap Pemangku Kepentingan maupun kelestarian lingkungan di sekitar BUMN.

4. Meningkatkan kontribusi BUMN dala perekonomian nasional.

Meningkatkan iklim yang kondusif bagi perkembangan investasi nasional.

\section{Corporate Social Responsibility dalam Perusahaan Perseroan (Persero)}

Menurut Undang-Undang Nomor 40 tahun 2007 tentang Perseroan Terbatas, Perseroan yang mejalankan kegiatan usahanya di bidang dan/atau bekaitan dengan sumber daya alam wajib melaksanakan Tanggung Jawab Sosial dan Lingkungan. Ketentuan ini diatur lebih lanjut dalam Peraturan Pemerintah Republik Indonesia nomor 47 tahun 2012 tentang Tanggung Jawab Sosial dan Lingkungan Perseroan Terbatas. Tanggung Jawab Sosial dan Lingungan ini disebut sebagai Program Bina Lingkungan (BL) yang diatur dalam Peraturan Menteri Negara Badan Usaha Milik Negara nomor PER-05/MBU/2007. Program Bina Linkungan (BL) yang dimaksudkan sama dengan program Corporate Social Responsibility. Corporate Social Responsibility adalah komitmen perusahaan atau dunia bisnis untuk berkontibusi dala pengembangan ekonomi 
yang berkelanjutan dengan memperhatikan tanggung jawab sosial perusahaan dan menitikberatkan pada keseimbangan antara perhatian terhadap aspek ekonomis, sosial, dan lingkungan. (Hendrik, 2012: 1). Pelaksanaan Corporate Social Responsibility selain diatur dalam undangundang, peraturan pemerintah, keputusan menteri juga didukung dengan ISO 26000.

\section{Transparasi}

Menurut Dwiyanto (2010:38) dalam Umami dan Nurodin (2017) transparasi adalah sebagai penyediaan informasi tentang pemerintahan bagi publik dan dijaminnya kemudahan didalam memperoleh informasi-informasi yang akurat dan memadai. Perwujudan tata kelola perusahaan yang baik mensyaratkan adanya keterbukaan, kelengkapan informasi, dan kemudahan masyarakat untuk memperoleh informasi perusahaan. Informasi yang tersedia harus memadai agar dapat dimegerti dan dipantau oleh pihak-pihak yang berkepentingan dan informasi tersebut bersifat bebas. Menurut Imam dan Amin (2002: 16) hal-hal yang harus dilaksanakan prinsip transparasti adalah :

a. Pengungkapan mencakup, akan tetapi tidak tebatas pada informasi yang material :

1. Hasil Keuangan dan operasi

2. Tujuan perusahaan

3. Kepemilikan saham utama dan hak-hak pemberian suara

4. Anggota dewan komisaris (board of directors) dan eksekutif kunci, dan remunerasi mereka

5. Faktor-faktor risiko material yang dapat diperkirakan

6. Isu material yang berkaitan dengan pekerja dan stakeholder yang lain

b. Informasi harus disiapkan, diaudit, dan diungkapkan sesuai dengan standar akuntansi, pengungkapan keuangan dan non-keuangan, dan audit yang bermutu tinggi.

c. Audit tahunan harus dilakukan oleh auditor independen agar memberikan keyakinan kepada pihak eksternal dan objektivitas atas cara laporan keuangan disusun dan disajikan.

d. Saluran peyebaran informasi harus memberikan akses yang wajar, tepat waktu dan efisien biaya terhadap informasi yang relevan untuk pemakai.

\section{Akuntabilitas}

Akuntabilitas merupakan penciptaan sistem pengawasan yang efektif berdasarkan keseimbangan pembagian kekuasaan antara board of commissioners, board of directors, shareholders, dan auditor (pertanggungjawaban wewenang, treaceable, reseonable) (Imam dan Amin, 2002: 7). Prinsip ini mejelaskan mengenai kejelasan fungsi, pelaksanaan, serta pertanggungjawaban manajemen perusahaan sehingga pengelolaan perusahaan dapat terlaksana secara efektif sehingga perusahaan harus dapat mempertanggungjawabkan kinerjanya dengan wajar dan transparan. Oleh karena itu, perusahaan harus dikelola secara benar, terstruktur dan sesuai kepentingan perusahaan namun dengan memperhitungkan kepentingan pemegang saham dan stakeholders lainnya.

\section{Pertanggungjawaban}

Prinsip pertanggungjawaban perusahaan adalah suatu kesesuaian (kepatuhan) tehadap peraturan perundangan yang berlaku didalam pegelolaan perusahaan. Penerapan prinsip pertanggungjawaban diharapkan dapat membuat perusahaan meyadari bahwa dalam kegiatan opersionalnnya seringkali meghasilkan dampak luar kegiatan perusahaan yang negatif dan harus ditanggung oleh masyarakat yang tedampak. Oleh karena itu, komisaris secara legal bertanggung jawab untuk menetapkan sasaran nilai 
perusahaan dan megembangkan kebijakan yang luas.

\section{Kemandirian}

Menurut Zarkasyi (2008: 40), untuk melancarkan pelaksanaan prinsip Good Corporate Governance perusahaan harus dikelola secara independen sehingga masing-masing organ perusahaan tidak saling mendominasi dan tidak mendominasi dan tidak dapat diintervensi oleh pihak lain. Kesimpulan yang didapatkan megenai prinsip kemandirian adalah keadaan dimana perusahaan dapat dikelola secara professional tanpa adanya benturan kepentingan individu dan pengaruh/ tekanan dari pihak manapun yang tidak sesuai dengan peraturan yang berlaku.

\section{Kewajaran}

Menurut Daniri (2005:12), secara sederhana kesetaraan kewajaran sebagai perlakuan adil dan setara di dalam memenuhi hak-hak stakeholders yang timbul berdasarkan perjanjian serta peraturan perundangan yang berlaku. Secara sederhana kewajaran dapat didefinisikan sebagai perlakuan yang adil dan setara di dalam memenuhi hak-hak stakeholders yang muncul berdasarkan perjanjian serta peraturan perundangundangan yang berlaku. Prinsip kewajaran ini diharapkan membuat asset perusahaan dikelola dengan baik dan hati-hati, sehingga dapat memberikan perlindungan kepentingan pemegang saham secara fair.

Penilaian Prinsip- prinsip Good Corporate Governance yang dituangkan dalam Pedoman Perilaku (Code of Conduct) Keputusan Direksi PT Jasa Marga (Persero) Tbk Nomor: 126/ KPTS/ 2019 sebagai berikut :

a. Transparasi (Transparency)

Perusahaan menjamin mengungkapkan informasi materiil dan relevan mengenai kondisi keuangan dan informasi lainnya secara jelas, memadai, akurat, dan tepat waktu serta mudah diaksesoleh stakeholders.

b. Akuntabilitas (Accountability)

Perusahaan menjamin kejelasan fungsi, hak, kewajiban, wewenang, dan tanggung jawab jajaran perusahaan yang memungkinkan pengelolaan perusahaan terlaksana secara efektif.

c. Bertanggung Jawab (Responsibility)

Perusahaan menjamin kesesuaian dalam melaksanakan aktiitas bisnisnya berdasarkan prinsip korporasi yang sehat, pemenuhan kewajiban terhadap pemerintah sesuai peraturan yang berlaku.

d. Kemandirian (Independency)

Perusahaan menjamin pengelolaan perusahaan secara professional tanpa benturan kepentingan dan pengaruh/tekanan dari pihak manapun.

e. Kewajaran (Fairness)

Perusahaan menjamin perlakuan yang adil dan setara dala memenuhi hak-hak stakeholders.

\section{Corporate Social Responsibility}

Corporate Social Responsibility adalah suatu bentuk tindakan yang berangkat dari pertimbangan etis perusahaan yang diarahkan untuk meningkatkan ekonomi yang diikuti dengan peningkatan kualitas hidup bagi karyawan berikut keluarganya, serta sekaligus peningkatan kualitas hidup masyarakat sekitar dan masyarakat secara lebih luas (Hadi, 2011: 48).

\section{METODE PENELITIAN Populasi dan Sampel}

Populasi dalam penelitian ini adalah divisi Community Developmet Program sebagai penanggungjawab pelaksanaan program Corporate Social Resposibility Transjawa Tollroad Regional Devision RO 2 Semarang tahun 2019 serta penerima 
program Corporate Social Resposibility yaitu kemitraan dan penerima bantuan bina lingkungan. Sampel dalam penelitian ini adalah manager Community Developmet Program dan pelaksana. Sedangkan dari penerima program Corporate Social Responsibility adalah 9 responden dari kemitraan bidang industri, jasa, perdagangan, perikanan, dan peternakan serta 6 responden dari bina lingkungan sarana ibadah, pendidikan, dan umum.

\section{Metode Pengumpulan Data}

Pengumpulan data melalui wawancara dilakukan dengan manager Community Developmet Program berjumlah 1 orang, pelaksana Community Developmet Program berjumlah 2 orang, perwakilan kemitraan setiap bidang berjumlah 9 orang, perwakilan penerima bantuan bina lingkungan setiap sarana berjumlah 6 orang.

\section{Metode Analisis Data}

Metode analisis data menggunakan metode deskriptif kualitatif yaitu menganalisis, menggambarkan, dan meringkas berbagai kondisi, situasi dari berbagai data yang dikumpulkan berupa hasil wawancara atau pengamatan mengenai masalah yang diteliti yang terjadi di lapangan (Wirartha, 2006 : 155).

\section{DISKUSI}

\section{Penerapan Good Corporate Governance}

Penerapan Good Corpate Governance bertujuan untuk meningkatan kinerja dan kepatuhan dalam pengimplementasian prinsip- prinsip Good Corporate Governance. Dalam penerapan ini, Jasamarga menyusun pedoman Tata Kelola Perusahaan atau Code of Corporate Governance). Sebagai acuan dalam pelaksaan kegiatan perusahaan, maka seluruh peraturan, keputusan atau kebijakan dalam bentuk apapun harus merujuk dan menjadikan Code of Corporate Governance sebagai acuan bagi organisasi perusahaan dan manajemen dalam mengelola perusahaan. Code of Corporate Government dalam implementasinya diikuti dengan berbagai kebijakan serta peraturan teknis sesuai kebutuhan perusahaan. Prinsip pedoman ini tetap sama dengan prinsip Good Corporate Governance yaitu transparasi (transparency), (accountability), (responsibility), akuntabilitas (independent), kewajaran (fairness). Prinsip tersebut dijadikan acuan dalam melaksanakan progam Corporate Social Responsibility.

\section{Pelaksanaan Corporate Social Responsibility}

Jasamarga melaksanaan kegiatan Corporate Social Responsibility dengan 2 (dua) program yaitu, Program Kemitraan dan Program Bina Lingkungan. Tahun 2019 Jasamarga RD RO 2 Semarang telah melaksanakan komitmennya dengan merealisasi 21 program Bina Lingkungan yang terbagi pada 8 sarana ibadah, 8 sarana pendidikan, dan 5 sarana umum serta 119 sektor kemitraan yang terdiri dari 32 industri, 23 jasa, 55 perdagangan, 1 perikanan, dan 8 peternakan. Pelaksanaan Corporate Social Responsibility ini diharapkan dapat memberikan dampak positif bagi perusahaan terutama menciptakan hubungan yang baik dengan masyarakat sekitar ruas jalan tol.

\section{Penerapan Prinsip- Prinsip Good Corporate Governance pada Program Corporate Social Responsibility Jasamarga \\ Penerapan Prinsip Transparasi (transparency)}

Jasamarga telah menyediakan sarana yang mudah diakses dan dipahami oleh masyarakat untuk mengetahui pelaksanaan kegiatan Corporate Social Responsibility 
yang dilaksanakan dilingkungannya. Sarana yang disediakan oleh Jasamarga untuk stakeholders dengan mengakses situs resmi Jasamarga yaitu www.jasamarga.com. Pada pelaksanaan program Corporate Social Responsibility di Jasamarga RD RO 2 Semarang terlihat sudah terlaksananya transparansi tersebut, hal ini dibuktikan dengan dibuatnya Laporan Keberlanjutan PKBL yang dapat di akses oleh stakeholders melalui situs resmi Jasamarga maupun jika masyarakat datang ke kantor Jasamarga Semarang untuk meminta laporan keuangaan juga dapat diberikan. Transparasi yang dilakukan oleh Jasamarga juga melalui penyaluran dana yang diberikan oleh perusahaan dengan mentransfer dana langsung ke rekening penerima bantuan.

Alur pelaksanaan program kemitraan telah diatur dalam Surat Direksi dan alur inipun disampaikan secara tertulis kepada mitra binaan baik melalui pertemuan yang diadakan oleh perusahaan maupun secara tertulis di surat perjanjian antara perusahaan dengan mitra binaan. Wujud transparasi yang dilakukan oleh Jasamarga selain laporan keberlanjutan yang dapat diakses di website resmi juga diwujudkan dalam proses pelaksanaan bina lingkungan. Transparasi ini diwujudkan melalui penyaluran non tunai atau dalam bentuk barang langsung yang diberikan perusahaan kepada penerima bina lingkungan. Hal ini bertujuan untuk mengurangi adanya kecurangan dalam penggunaan dana bina lingkungan.

Pelaksanaan bina lingkungan Jasamarga secara transparan telah dirasakan oleh semua penerima bina lingkungan baik dalam laporan, informasi serta alur yang disampaikan. Hanya saja, penyampain informasi belum secara terbuka dilakukan oleh perusahaan kepada masyarakat. Penyampaian ini diharapkan dapat membuat masyarakat merasakan adanya keberadaan perusahaan dalam keberlangsungan sosial.

\section{Penerapan Prinsip Akuntabilitas (acoountability)}

Dalam hal ini Jasamarga melakukan prinsip akuntabilitas bagi program Corporate Social Responsibility yaitu mempublikasikan sebagian kebijakan pelaksanaan Corporate Social Responsibility yang diharapkan dapat bermanfaat bagi staleholders dan shareholders serta Jasamarga juga melaksanakan BUMN Peduli sebagai wujud akuntabilitasnya terhadap Negara.

Jasamarga mengatur tata pengajuan keikut sertaan program kemitraan yang diatur dalam Surat Direksi tentang pelaksanaan program kemitraan dan bina lingkungan. Alur ini disampaikan kepada semua mitra binaan hanya melalui pertemuan yang dilaksanakan perusahaan. Inilah kelemahan yang dimiliki Jasamarga dalam prinsip akuntabilitas yaitu tidak dipublikasikan secara terbuka kepada masyarakat. Kejelasan tugas divisi Community Development Program dalam program kemitraan ini yaitu menerima serta meseleksi kelengkapan proposal calon mitra binaan yang kemudian dilanjutkan dengan survey. Penerapan prinsip akuntabilitas yang lain diwujudkan dengan tidak adanya pengenaan sanksi dalam keterlambatan pembayaran angsuran pinjaman. Hal ini dinilai sangat membantu mitra binaan dan tujuan Jasamarga murni untuk membantu pemberdayaan usaha masyarakat. Kebijakan mengenai tidak adanya pengenaan sanksi ini dinilai sangat memandang kepentingan stakeholders sehingga tidak merugikan salah satu pihak.

Alur pelaksanaan program bina lingkungan ini disampaikan kepada penerima bina lingkungan secara lisan pada saat calon penerima bina lingkungan memberikan proposal kepada perusahaan. Divisi Community Development Program dinilai sangat membantu penerima dalam pelaksaan program bina lingkungan karena tugas divisi ini tidak jauh beda dengan tugasnya saat melaksanakan program 
kemitraan yaitu melakukan pemeriksaan kelengkapan proposal serta survey awal. Kejelasan kebijakan perusahaan dinilai sudah sangat jelas dan telah mementingan kepentingan para stakeholders serta dan shareholders. Kejelasan kebijakan ini diharapkan dapat membantu perusahaan agar tujuan pelaksanaan program bina lingkungan ini dapat tersampaikan dengan baik dan jelas kepada semua penerima program bina lingkungan.

\section{Penerapan prinsip Tanggungjawab (responsibility)}

Jasamarga telah menerapkan prinsip tanggung jawab karena pada laporan keberlanjutan perusahaan telah dijelaskan komitmennya dalam melaksanakan program Corporate Social Responsibility. Melalui pelaporan yang diberikan perusahaan telah mampu menerapkan prinsip tanggung jawab ini terlebih kepada stakeholders dan shareholders. Tetapi tanggung jawab ini juga dimaksudkan bahwa perusahaan telah memenuhi komitmennya kepada semua mitra binaan dan penerima bina lingkungan selama proses pelaksanaan program Corporate Social Responsibility.

Penerapan prinsip tanggung jawab dalam pelaksanaan program kemitraan dilihat dari perusahaan dapat memenuhi komitmennya kepada mitra binaan baik berupa janji kesepakatan pencairan dana maupun janji mengenai hak yang diberikan kepada mitra. Penilaian ini merupakan hal yang sangat penting dalam membangun reputasi perusahaan. Karena apabila dalam janjinya saja perusahaan dirasa belum mapu memenuhi komitmennya maka pertanggung jawaban selajutnya patut untuk dipertanyakan. Janji atau komitmen yang diberikan oleh perusahaan juga adalah hal yang tidak dapat disepelekan. Disisi lain, tanggapan perusahaan terhadap masukan yang diberikan oleh mitra binaan juga merupakan pengimplementasian prinsip tanggung jawab. Bagaimana perusahaan bertanggung jawab untuk menindaklanjuti masukan - masukan yang diberikan oleh masyarakat terkhusus mitra binaan dalam pelaksanaan program mitra binaan ini.

Pengimplementasian prinsip tanggung jawab dalam program ini dapat dilihat juga dari bagaimana perusahaan dapat memenuhi komitmennya terkait kesepakatan yang diberikan kepada penerima bina lingkungan. penerima bina lingkungan sangat merasakan adanya rasa tanggung jawab perusahaan terkait komitmennya terkhusus terkait dengan pertanggung jawaban perusahaan kepada lingkungan atas kegiatan operasinya yang ditunjukkan melalui program kemitraan dan program bina lingkungan yang telah terlaksana.

\section{Penerapan Prinsip Kemandirian (independency)}

Kemandirian artinya perusahaan harus dikelola secara independent sehingga masing-masing organ perusahaan tidak saling mendominasi dan tidak diintervensi oleh pihak lain. Oleh karena itu Jasamarga mensyaratkan adanya pengawasan masyarakat lokal dalam pelaksanaan Corporate Social Responsibility baik itu program kemitraan ataupun program bina lingkungan. hal ini dilakukan agar tidak ada dominasi dari pembuat program Corporate Social Responsibility dan tidak diintervensi karena program Corporate Social Responsibility ini dibuat berdasarkan hasil diskusi dan survey dari stakeholders.

Pengawasan masyarakat lokal ini bertujuan sebagai pengawas atas berlangsungnya program kemitraan yang dilaksanakan di daerah tersebut. Setiap calon mitra binaan saat mengajukan proposal terkait peminjaman modal tersebut harus diketahui sampai ke kelurahan daerah tersebut. Hal ini disampaikan dalam Surat Direksi tentang program kemitraan dan bina lingkungan bahwa mitra binaan harus 
memiliki surat izin usaha atau surat keterangan usaha dari pihak berwenang.

Penerapan prinsip kemandirian dalam program kemitraan ini telah dilaksanakan dengan baik. Penerapan prinsip kemandirian pada program bina lingkungan selain akan adanya pengawasan dari masyarakat lokal, perusahaan juga memiliki vendor untuk keperluan pembelanjaan barang yang dibutuhkan untuk program bina lingkungan. negosiasi pembelanjaan melalui vendor langsung dilakukan dengan Jasamarga pusat tanpa adanya intervensi dari Jasamarga cabang Semarang. Hal ini telah membuktikan bahwa perusahaan tidak mendominasi kepentingan perusahaan saja. Pembelanjaan barang melalui vendor juga diketahui oleh penerima bina lingkungan sehingga barang yang diberikan sudah disepakati bersama antara perusahaan dengan penerima bina lingkungan.

\section{Penerapan Prinsip Kesetaraan dan Kewajaran (fairness)}

Kesetaraan dan kewajaran ini artinya perusahaan harus senantiasa memperhatikan kepentingan pemegang saham dan pemangku kepentingan lainnya. Program Corporate Social Responsibility Jasamarga selama ini dijalankan oleh Jasamarga juga mempengaruhi profit perusahaan oleh karena itu kepentingan pemegang saham merasa tidak rugi untuk menyimpan sahamnya di Jasamarga. Selain itu, dampak di masyarakat adalah dengan adanya program ini sehingga masyarakat menjadi loyal dan percaya kepada Jasamarga karena kehidupan mereka bisa terbantu dan lebih baik dari sebelumnya.

Pembagian kesempatan untuk program kemitraan dan program bina lingkungan juga menerapkan prinsip ini dilihat dari bagaimana perusahaan mengambil keputusan persetujuan untuk dilaksanakan.

\section{Penilaian Penerapan Prinsip Good Corporate Governance}

Berdasarkan dengan Keputusan Direksi PT Jasa Marga (Persero) Tbk Nomor 126/KPTS/2019 dan mengacu pada Keputusan Sekretaris Kementrian Badan Usaha Milik Negara Nomor SK16/S.MBU/2012 menghasilkan seperti berikut :

Tabel 1 Penilaian Penerapan Prinsip Good Corporate Governance

\begin{tabular}{|c|c|c|c|c|}
\hline No & Praktik yang Dinilai Diuij & Bobot & Nilai & $\begin{array}{l}\text { Capaian } \\
(\%)\end{array}$ \\
\hline & TRANSPARASI & & & \\
\hline 1. & $\begin{array}{l}\text { Pengungkapan informasi program CSR secara ielas, } \\
\text { memadai, akurat, tepat walku. }\end{array}$ & 0.25 & 0.50 & 12.5 \\
\hline 2. & Mempublikasikan laporan keuangan CSR & 0.25 & 1 & 25 \\
\hline 3. & Kemudahan akses terhadap informasi CSR & 0.25 & 1 & 25 \\
\hline \multirow[t]{3}{*}{4.} & $\begin{array}{l}\text { Sebijiakan perusahaan tertulis dan diksomunikasikan } \\
\text { kepada pemangku kepentingan }\end{array}$ & $\overline{0.25}$ & $\overline{0.75}$ & 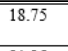 \\
\hline & $\begin{array}{ll}\text { Total } \\
\text { tal }\end{array}$ & 1 & & 81.25 \\
\hline & AKUNTABILITAS & & & \\
\hline 1. & $\begin{array}{l}\text { Kejelasan funggi, hak, kewvajiban, wewenang, dan } \\
\text { tanggung jawab organ }\end{array}$ & 0.33 & 0.75 & 24.75 \\
\hline 2. & Adanxa ukuran kinerja program CSR & 0.33 & 1 & 33 \\
\hline \multirow[t]{2}{*}{3.} & $\begin{array}{l}\text { Perusahaan memiliki pedgman perilaku (code of } \\
\text { conduct) }\end{array}$ & 0.34 & 1 & 34 \\
\hline & Total & 1 & & 90.76 \\
\hline 1 & $\begin{array}{l}\text { PERTANGGUNGJAWABAN } \\
\text { Kepatuhan terhadan peraturan perundang-undangan }\end{array}$ & & & \\
\hline \multirow[t]{2}{*}{2.} & $\begin{array}{l}\text { Kepatuhan terhadap peraturan perundang-undangan } \\
\text { Perusahaan bertanggung jawab atas kegiatan CSR }\end{array}$ & 0.50 & $\frac{1}{1}$ & $\begin{array}{l}50 \\
50\end{array}$ \\
\hline & Total & 1 & & 100 \\
\hline 1. & $\begin{array}{l}\text { KEMANDIRIAN } \\
\text { Perusahaan dikelola secara professional tanpa adanyal } \\
\text { benturan bepentingan dan pengaruh dari pihalk } \\
\text { manapun }\end{array}$ & 0.50 & 0.50 & 25 \\
\hline \multirow[t]{2}{*}{2.} & Pengawasan program CSR gleh masxarakat local & 0.50 & 1 & 50 \\
\hline & $\begin{array}{l}\text { Total } \\
\text { KEWAJARAN } \\
\end{array}$ & 1 & & 75 \\
\hline 1. & $\begin{array}{l}\text { Perusahaan bersikap. adil dan setara dalam memenuhi } \\
\text { hak yang diberikan }\end{array}$ & 0.33 & 1 & 33 \\
\hline 2. & $\begin{array}{l}\text { Perusahaan memberikan kesempatan yntuk } \\
\text { memberikan massukan dan mensampaikan pendapat } \\
\text { mengenai pelaksanaan program CSR }\end{array}$ & 0.33 & 1 & 33 \\
\hline 3. & $\begin{array}{l}\text { Perusahaan memberikan kesempatan yang sama } \\
\text { dalam pelaksanaan CSR }\end{array}$ & 0.34 & 1 & 34 \\
\hline & Total & 1 & & 100 \\
\hline
\end{tabular}

Sumber: Data Sekunder yang Diolah, 2020

Setiap faktor dari masing-masing prinsip Good Corporate Governance memiliki bobot yang sama, misal tiap faktor pada prinsip Transparansi memiliki bobot 0,25 karena terdapat 4 faktor yang dinilai. Demikian juga dengan pembobotan factor pada prinsip Akuntabilitas, Pertanggungjawaban, Kemandirian dan Kewajaran. Kemudian Sesuai dengan Sekretaris Kementrian Badan Usaha Milik Negara Nomor SK-16/ S.MBU/ 2012, tingkatan pemenuhan factor yang diuji dikategorikan dalam lima tingkatan, yaitu $0,0,25,0,50,0,75,1$, dengan ketentuan sebagai berikut: 
Tabel 2. Kategori Tingkat Pemenuhan Faktor yang Diuji

\begin{tabular}{|l|l|}
\hline \multicolumn{2}{|c|}{ Tingkat pemenuhan } \\
\hline 0 & Tidak ada \\
\hline 0,25 & $\begin{array}{l}\text { Memenuhi sebagian kecil ( >0 } \\
\text { s.d. 50\%) kriteria }\end{array}$ \\
\hline 0,50 & $\begin{array}{l}\text { Memenuhi sebagian besar ( }>50 \% \\
\text { s.d. 75\%) kriteria }\end{array}$ \\
\hline 0,75 & $\begin{array}{l}\text { Memenuhi sebagian (>75\% s.d. } \\
85 \%) \text { kriteria }\end{array}$ \\
\hline 1 & $\begin{array}{l}\text { Memenuhi seluruh } \\
\text { kriteria }\end{array}$ \\
\hline
\end{tabular}

Sumber : Sekretaris Kementrian Badan Usaha Milik Negara Nomor SK-16/ S.MBU/ 2012.

Tingkat pemenuhan penuhan parameter selanjutnya dikalikan dengan bobot parameter sehingga menghasilkan nilai capaian (tertimbang) parameter yang bersangkutan. Penilaian dapat di klasifikasikan sebagai berikut :
a. Nilai diatas 85 : Sangat Baik
b. $\quad 75<$ Nilai $\leq 85$ : Baik
c. $\quad 60<$ Nilai $\leq 75$ : Cukup Baik
d. $\quad 50<$ Nilai $\leq 60 \quad$ : Kurang Baik
e. Nilai $\leq 50 \quad$ : Tidak Baik

Kekurangan Penerapan Prinsip Good Corporate Governance pada Program Corporate Social Responsibility .

Kekurangan PT Jasa Marga (Persero) Tbk khususnya dalam mengimplementasikan kelima prinsip Good Corporate Governance terhadap program Corporate Social Responsibility adalah pada saat mengimplementasikan prinsip transparasi karena perusahaan kurang menginformasikan mengenai program yang dijalankan kepada masyarakat luas terlebih kepada daerah terdampak operasi perusahaan, serta beberapa oknum menggunakan jabatannya untuk dapat menjadi bagian dalam program Corporate Social Responsibility perusahaan. Kekurangan lain yang dihadapi oleh PT Jasa Marga terdapat pada prinsip akuntabilitas mengenai kepastian regulasi antara Jasamarga pusat dengan Jasamarga cabang. Kekurangan juga dirasakan dalam penerapan prinsip kemandirian. Adanya penggunaan jabatan dalam perolehan program Corporate Social Responsibility dinilai perusahaan tidak independen dengan kata lain adanya campur tangan dalam pengambilan keputusan untuk mementukan mitra binaan dan juga penerima bina lingkungan.

\section{PENUTUP Simpulan}

1. Prinsip transparasi pada pelaksanaan Corporate Social Responsibility Jasamarga RD RO 2 Semarang telah dijalankan dengan baik, yaitu keterbukaan perusahaan terkait laporan keberlanjutan yang mencakup program kemitraan dan program bina lingkungan yang dilaksanakan oleh perusahaan dengan baik dan mudah diakses oleh pemangku kepentingan perusahaan melalui website resmi Jasa Marga.

2. Prinsip akuntabilitas pada pelaksanaan Corporate Social Responsibility Jasamarga RD RO 2 Semarang telah dijalankan dengan sangat baik, yaitu perusahaan telah mempertanggungjawabkan kinerjanya dengan transparan dan wajar. Penerapaan prinsip ini tidak lepas dari penerapan prinsip transparasi karena prinsip transparasi juga telah dilaksanakan oleh perusahaan dengan cukup baik maka hal ini mendukung terhadap pelaksanaan prinsip 
akuntabilitas. Disisi lain, perusahaan telah menyampaikan tugas dan wewenang setiap organ perusahaan dengan baik dan jelas.

3. Prinsip pertanggungjawaban pada pelaksanaan Corporate Social Responsibility Jasamarga RD RO 2 Semarang telah dilaksanakan dengan sangat baik, hal ini dibuktikan melalui pertanggung jawaban perusahaan atas pemberian hak kepada semua mitra binaan dan bina lingkungan terkait pelaksanaan Corporate Social Responsibility. Perusahaan telah memenuhi semua kewajiban perusahaan kepada semua mitra binaan maupun penerima bina lingkungan dengan sangat baik.

4. Prinsip kemandirian pada pelaksanaan Corporate Social Responsibility Jasamarga RD RO 2 Semarang telah dilaksanakan dengan cukup baik, hal ini dilaksanakan melalui pengawasan dalam pelaksanaan Corporate Social Responsibility diketahui oleh masyarakat lokal yang bersifat netral atau tidak berpihak kepada perusahaan maupun penerima program Corporate Social Responsibility .

5. Prinsip keadilan pada pelaksanaan Corporate Social Responsibility Jasamarga RD RO 2 Semarang telah dilaksanakan dengan sangat baik, hal ini diwujudkan dengan keadilan dalam menentukan mitra binaan perusahaan dan penerima bina lingkungan yang berhak mendapatkannya dengan tetap mementingkan kepentingan stakeholders.

6. Kekurangan ini terdapat pada beberapa prinsip yaitu penerapan dalam prinsip transparasi, akuntabilitas, kemandirian. Kekurangan dalam penerapan prinsip transparasi yaitu kurangnya keterbukaan perusahaan akan informasi pelaksanaan Corporate Social Responsibility yang dilaksanakan oleh perusahaan. Kekurangan lain yaitu pada penerapan prinsip akuntabilitas. Dalam pemetaan tugas dan wewenang dirasa perusahaan kurang bertanggung jawab dalam pemberian kepastian kepada calon penerima bina lingkungan mengenai tanggal pencairan dana yang akan diberikan oleh perusahaan.

\section{Implikasi Manajerial}

Perbaikan implementasi prinsip transparasi oleh pihak Jasamarga dapat dilakukan melalui keterbukaan perusahaan mengenai informasi pelaksanaan program Corporate Social Responsibility yaitu adanya program bina lingkungan dan program kemitraan untuk masyarakat terkhusus masyarakat terdampak operasional perusahaan yang program tersebut merupakan bentuk tanggung jawab perusahaan terhadap lingkungan sekutarnya. Hal ini dapat dilakukan melaui website perusahaan dan dapat melalui sosialisasi dengan masyarakat daerah operasional jalan tol sehingga informasi pelaksanaan kegiatan Corporate Social Responsibility dapat diketahui oleh seluruh masyarakat dan tidak hanya bagi kelompok kecil masyarakat dengan maksud untuk meningkatakan adanya penilaian masyarakat terhadap keberadaan perusahaan dari segi ekonomi dan sosial. Perbaikan implementasi prinsip kemandirian tidak jauh dari perbaikan implementasi transparasi yang telah dijelaskan, bahwa perusahaan harus terbuka mengenai informasi pelaksanaan Corporate Social Responsibility kepada masayarakat luas. Perusahaan harus tetap memprioritaskan kebutuhan masyarakat sekitar ruas jalan tol sebagai bentuk tanggung jawab perusahaan kepada sekitarnya. 
Praxis : Jurnal Sains, Teknologi, Masyarakat dan Jejaring | Vol. 3 | No. 2 | Maret 2021

\section{DAFTAR PUSTAKA}

Komite Nasional Kebijakan Governance, 2006. Pedoman Umum Good Public Governance Indonesia.

Undang-Undang Republik Indonesia No. 19 Tahun 2003 tentang Badan Umum Milik Negara.

Peraturan Menteri Badan Umum Milik Negara Nomor 1 Tahun 2011 tentang Penerapan Tata Kelola Perusahaan Yang Baik (Good Corporate Governance) Pada Badan Usaha Milik Negara.

FCGI, 2001. Corporate Governance: Tata Kelola Perusahaan Jilid 1. Jakarta.

Undang- Undang Republik Indonesia No. 40 Tahun 2007 tentang Perseroan Terbatas.

Untung, Hendrik Budi. 2012. Corporate Social Responsibility. Yogyakarta: Sinar Grafika.

Umami, Risya dan Idang Nurodin. 2017. Pengaruh Transparasi Dan Akuntabilitas Terhadap Pengelolaan Keuangan Desa. Jurnal Ilmian Ilmu Ekonomi. Volume 6. Nomor 11.

Tunggal, Imam Sjahputra dan Amin Widjaja Tunggal.2002. Membangun Good Corporate Governance (GCG). Jakarta: Harvindo.

Zarkasyi, Moh. Wahyudin. 2008. Good Corporate Governance pada Badan Usaha Manufaktur, Perbankan dan Jasa Keuangan Lainnya. Bandung: Alfabet

Daniri, Mas Achmad. 2005. Good Corporate Governance (GCG): Konsep dan Penerapannya dalam Konteks Indonesia. Jakarta: Ray Indonesia.

Hadi, Nor. 2011. Corporate Social Responsibility. Corporate Social Responsibility. Yogyakarta: Graha Ilmu.

Purhantara, Wahyu. 2010. Metode Penelitian Kualitatif Untuk Bisnis. Yogyakarta: Graha Ilmu.

Febriani, Happy Putri. 2013. Pemberian Motivasi Kepala Perpustakaan Dalam
Meningkatkan Prestasi Kerja Pustakawan Di UPT Perpustakaan IAIN Surakarta. Jurnal Psikologi UNDIP.Volume 1. Nomor 3.

Sugiyono. 2014. Metode Penelitian Pendidikan (Pendekatan Kuantitatif, dan R\&D). Bandung: Alfabeta.

Wirartha, I Made. 2006. Metode Penelitian Sosial Ekonomi. Yogyakarta: Andi Offset. 